\title{
EDITORIAL
}

\section{CONTEMPORARY MILITARY CHALLENGES IN ENGLISH - A PROBLEM OR AN OPPORTUNITY}

Dear readers,

You are looking at a new edition of the Contemporary Military Challenges, which includes contributions by the authors employed in Slovenian defence system; all except for one work in the Slovenian Armed Forces. This continues our tradition that the last issue in a year includes Slovenian military authors.

The previous, thematic, issue devoted to hybrid threats was published entirely in English. It drew different responses from the readers, although some articles have also been published in Slovene on our website. We have received a letter from a reader, who specifically highlighted the problem of publishing a Slovenian publication in English. He agreed that his letter be published on the website of the Contemporary Military Challenges, where our reply is also published (in Slovene). The reader mainly underlined his concern about the preservation and development of Slovene military language. Indirectly, he listed a few hesitations for which we believe deserve a few explanations related to the publication of the Contemporary Military Challenges.

Within the framework of developing military professional literature, which is imposed by the Defence Act, the Slovenian Armed Forces publish several different periodicals, such as Vojaškošolski zbornik (Military Education Journal), Vojaška zgodovina (Military History) and other occasional publications (Prava smer, Prvi, Modri, etc.). The Ministry of Defence, on the other hand, also publishes a biweekly Slovenska vojska (Slovenian Armed Forces).

Among all the publications published by the Slovenian Armed Forces, the Contemporary Military Challenges are the only publication ranking among scientific and professional publications. It is included in the Slovenian Research Agency's 
list of magazines. One of the quality conditions for publications to be included in this list is that one of the four issues in a year be published in English. In line with the higher education legislation, the publication of articles in a periodical of such rank provides authors with habilitation points. Therefore, the authors take this as a form of motivation, both, for external scientists and experts as well as for those employed in Slovenian defence system.

The importance of developing quality Slovenian military scientific and professional subjects has been discussed in several articles by many Slovenian authors ${ }^{1}$. As for the younger generations, a number of experts and scientists from various faculties and other institutions have cooperated with our Editorial Board. Since the publication was indexed in an international database, the interest of foreign and Slovenian authors to publish in our publication has increased. All in all, the number of quality writers in Slovenian defence system has been increasing, which is evident from the articles and statistics published on our website.

The Editorial Board has developed links and cooperation with various command and staff schools in the EU and NATO. We exchange experiences, knowledge and new findings. We wish for other military experts and scientists to be able to publish their articles in the Slovenian Armed Forces publication, but our main wish is for other people from partner countries to be able to learn about our knowledge and experiences.

A value added undoubtedly lies in the exchange of articles with foreign military scientific and professional publications, and cooperation among editorial boards ${ }^{2}$. We have developed cooperation with the institutions such as Center for Civil-Military Relations from Monterey, USA; European Center for Security Studies George C. Marshall from Germany; Research Institute for European and American Studies from Greece and others.

Different experts take part in the process of developing Slovenian military literature, including proofreaders and translators. The cooperation of both has resulted in the publication of several Slovenian terminology handbooks and dictionaries ${ }^{3}$. We can thus write with an easy conscience that, we, at the Ministry of Defence and the Slovenian Armed Forces are doing our best to provide for quality development of Slovenian military literature and terminology. However, it is true that a lot remains to be done.

\footnotetext{
E.g.: Kranjc, Marijan F. (2005); Žabkar, Anton (2003); Žabkar, Anton (2004); Žabkar, Anton, Svete, Uroš (2008).

2 E.g.: Parameters and Military \& Society (USA), Romanian Military Thinking (Romania), Vojnotehnički glasnik (Serbia), Boletim, Proelium in Revista de Ciências Sociais e Politicas (Portugal).

3 E.g. Dictionary of Engineering, Slovene-German military dictionary, Language handbook for interpreters and translators.
} 
Of course, the above-mentioned facts are not perceived as a reason to rest on our laurels. International security environment is a very dynamic one and the Slovenian Armed Forces constitute a part of it. Our daily routine in this environment represents a constant challenge and demonstrates a need for confirming our quality.

Personally, I am convinced that the Slovene language with a long tradition in the Slovenian Armed Forces is under no threat. I believe that today's membership and the role of our country in international structures differs a great deal from the one from our former common country. The proofreaders and translators, who have been supporting the making of the Contemporary Military Challenges for thirteen years, perceive the development of their domain as an every-day challenge rather than a problem. On the other hand, it also represents an excellent opportunity for the print media, the development of Slovenian military science and professional literature, and the exchange of knowledge with others.

The opinions of our readers are a precious stimulation for the reflexions about the accuracy of our goals and, of course, about the best way to attain them. In addition to other factors, our decisions have lately also been largely influenced by the financial aspects of publishing our publication.

As usual, we kindly invite all who would like to contribute to the development of military subjects to participate in the making of the Contemporary Military Challenges. You are, of course, welcome to contribute polemics and comments; however, professional and scientific articles written in line with the "Instructions for the Authors of Papers", which we publish at the end of our publication, are a better way of developing the quality of military literature.

In this issue of the Contemporary Military Challenges, Tanja Pečnik introduces a subject entitled Geopolitical Determination of the Slovenian Armed Forces Formation of Multinational Forces in the Area of Western Balkans. Her aim was to verify the possibility of Slovenia or any of other former Yugoslav republics thinking about expanding their geopolitical influence by building closer military relations.

Comprehensive operations planning in NATO has been discussed by Jože Grozde who claims that the resolution of crisis in post-Cold War conflicts by using military force has proved ineffective, since it does not guarantee significant improvements in the security situation. NATO has introduced comprehensive operations planning in support of the comprehensive approach of the international community to the resolution of complex crises.

In his Command and Control Paradigm in the Enforcement of Military Discipline, Vojko Obrulj discusses military discipline from two aspects, i.e. as an individual's attitude towards military discipline, and as a behavioural discipline. 
Regulations or Code of Conduct and Behaviour for the Providers of Education and Training in the Slovenian Armed Forces is a subject which stimulated the writing of Mojca Pešec. The providers of education and training are obliged to attain the highest competence standards and to respect the values regulating mutual relationships of the participants. She therefore proposes the adoption of such a document.

In his article entitled Views of Slovenian Armed Forces Members on Postings to International Duties Abroad, Branko Podbrežnik presents the results of a research he conducted among these service members. He has found that, in this respect, the latter have to cope with various challenges concerning them personally, their life and work, as well as the life of their families. Finally, the author discusses the way the defence system provides its support.

The Challenges of Development Strategy Regarding Information and Communications Technology Services have inspired the writing of Mihael Nagelj. According to his findings, the experiences regarding the implementation of business strategies in modern organisations had shown that strategies can only be implemented by using advanced information technologies.

We wish you pleasant reading. Perhaps the above-mentioned subjects will inspire an idea for a new or an already familiar subject which could be presented to others in a new or a different way. 